\title{
Etiology analysis and computed tomography imaging of a tonsillar inflammatory myofibroblastic tumor: report of an immunocompetent patient and brief review
}

\author{
Yun-Zhen Luo ${ }^{1,2}$, Li-Bo Dai ${ }^{1}$, Shui-Hong Zhou ${ }^{1 *}$, Xing-Mei Luo ${ }^{1}$, Jun Fan ${ }^{3}$ and Ling-Xiang Ruan ${ }^{4}$
}

\begin{abstract}
Objectives: The etiology of Inflammatory myofibroblastic tumor(IMT) is contentious. In this study, we used computed tomography (CT) to examine tonsillar IMT and further analyzed the etiology of this entity.

Methodology: We presented CT features of left tonsillar IMT and reviewed the English-language literature published between 1984 and 2011.

Results: To our knowledge, there are only six published cases of tonsillar IMT including the present case. Two patients were asymptomatic at initial presentation. Two patients were taking immunosuppressants, and one was pregnant and in an immunomodulated state. CT of our patient revealed a $2.6 \times 1.8 \mathrm{~cm}$ irregular soft tissue mass between the left tonsil and the base of the tongue. It did not invade surrounding structures and was not enhanced on contrast-enhanced imaging.

Conclusions: Tonsillar IMT may be a benign tumor. We suggest that preoperative recognition of tonsillar IMT by $C T$ may be important to avoid unnecessary expanded surgery.
\end{abstract}

Keywords: Inflammatory myofibroblastic tumor, Tonsil, Etiology, Computed tomography, Treatment

\section{Background}

Inflammatory myofibroblastic tumor (IMT) is a rare mesenchymal tumor [1]. The etiology of IMT is contentious, and debate exists as to whether IMT is benign or malignant [1-3]. Some IMTs are found to be associated with systemic inflammatory disorders [1,4], autoimmune diseases [5], or neoplasms [6]. Its prognosis and behavior are controversial. Most patients with IMT have a good prognosis and can be cured by resection. Recent evidence shows that IMTs may have different etiologies and clinicopathologic features at different sites $[3,7,8]$.

Tonsillar IMT is rare; we reviewed the English-literature regarding tonsillar IMT and only five previous reports covered this topic [9-13]. Two of the five patients were taking immunosuppressants, and one was pregnant

\footnotetext{
* Correspondence: zhouyunzhoush@163.com

'Department of Otolaryngology, The First Affiliated Hospital, College of

Medicine, Zhejiang University, Hangzhou, Zhejiang 310003, China

Full list of author information is available at the end of the article
}

and in an immunomodulated state. We herein report the sixth case of tonsillar IMT in the English-language literature in an immunocompetent patient and first describe the computed tomography $(\mathrm{CT})$ imaging features of tonsillar IMT.

\section{Case presentation}

A 51-year-old woman presented with a 3-year history of a progressively enlarging mass in the left palatine tonsil. The mass had been approximately $0.5 \times 0.5 \mathrm{~cm}$ during a routine check-up 3 years previously. The patient denied sore throat, fever, malaise, dysphagia, and dyspnea. The patient had no history of generalized immune deficiency, leukemia, malignant disease, diabetes mellitus, or use of immunosuppressive drugs, including corticosteroids. The patient also denied alcohol and tobacco abuse and any previous surgery or trauma. The patient had not visited a doctor for evaluation of the mass. Six months prior to presentation, the patient felt a dry itch in her throat and the

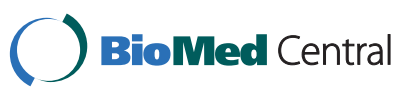

(c) 2012 Luo et al; licensee BioMed Central Ltd. This is an Open Access article distributed under the terms of the Creative Commons Attribution License (http://creativecommons.org/licenses/by/2.0), which permits unrestricted use, distribution, and reproduction in any medium, provided the original work is properly cited. 
mass had progressively enlarged. In June 2011, the patient presented to our department. Physical examination showed a $2.5 \times 2 \mathrm{~cm}$ irregular mass in the upper pole of the left palatine tonsil. There was no adenopathy. The rest of the physical examination results were normal. CT of the pharynx showed a $2.6 \times 1.8 \mathrm{~cm}$ irregular soft tissue mass between the left tonsil and the base of the tongue (Figure 1A) with no enhancement on contrast-enhanced imaging, and no enlargement of the lymph nodes (Figure 1B). Laboratory examination revealed a normal complete blood count and normal erythrocyte sedimentation rate. Serological tests were positive for anti-Epstein-Barr virus (EBV) IgG and anti- cytomegalovirus (CMV) IgG, and negative for anti-EBV IgM, anti-CMV IgM, and antihuman immunodeficiency virus (HIV) antibodies. There were no other abnormalities on systemic or dermatological examinations. Chest X-ray and abdominal ultrasonography (USG) results were normal.

On June 17, 2011, the mass and left tonsil were excised completely under general anesthesia without any complications (Figure 1C). Pathological analysis of frozen sections showed an inflammatory pseudotumor. Routine pathological examination demonstrated that the tumor was composed of short spindle cells arranged in a weaving pattern. The spindle cells in some areas were rich; some cells showed atypia and mitosis and were mixed with inflammatory cells, such as lymphocytes, and plasma cells arranged as clusters (Figure 2A). Immunohistochemical (IHC) analysis was positive for the expression of desmin (Figure 2B), and focally positive for S-100 protein. In contrast, IHC analysis was negative for CD117, CD34, smooth muscle actin, caldesmon, and cytokeratin. Further molecular pathological investigation by polymerase chain reaction (PCR) did not reveal CMV or EBV infection. There was no evidence of recurrence after 8 months of follow-up.

\section{Conclusions}

IMT may occur at nearly every site of the body [8], including the lungs [3], hypopharynx [4], central
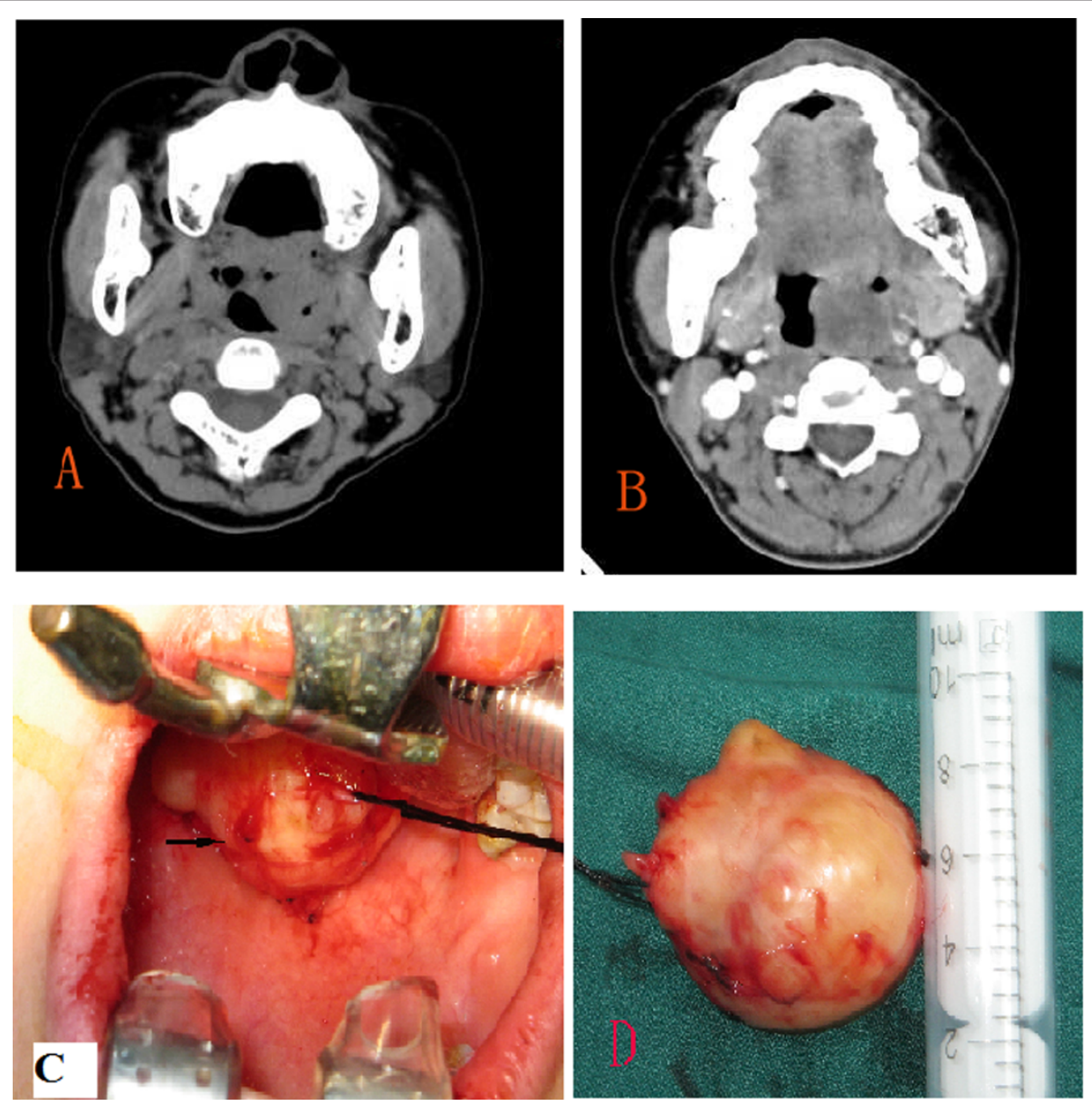

Figure $1 \mathrm{CT}$ of pharynx showed that a $2.6 \mathrm{~cm} \times 1.8 \mathrm{~cm}$ irregular soft tissue mass between the left tonsil and the base of the tongue (A), with no enhanced on contrast-enhanced imaging(B).C: The mass and left tonsil were excised completely. D: surgical specimen. 


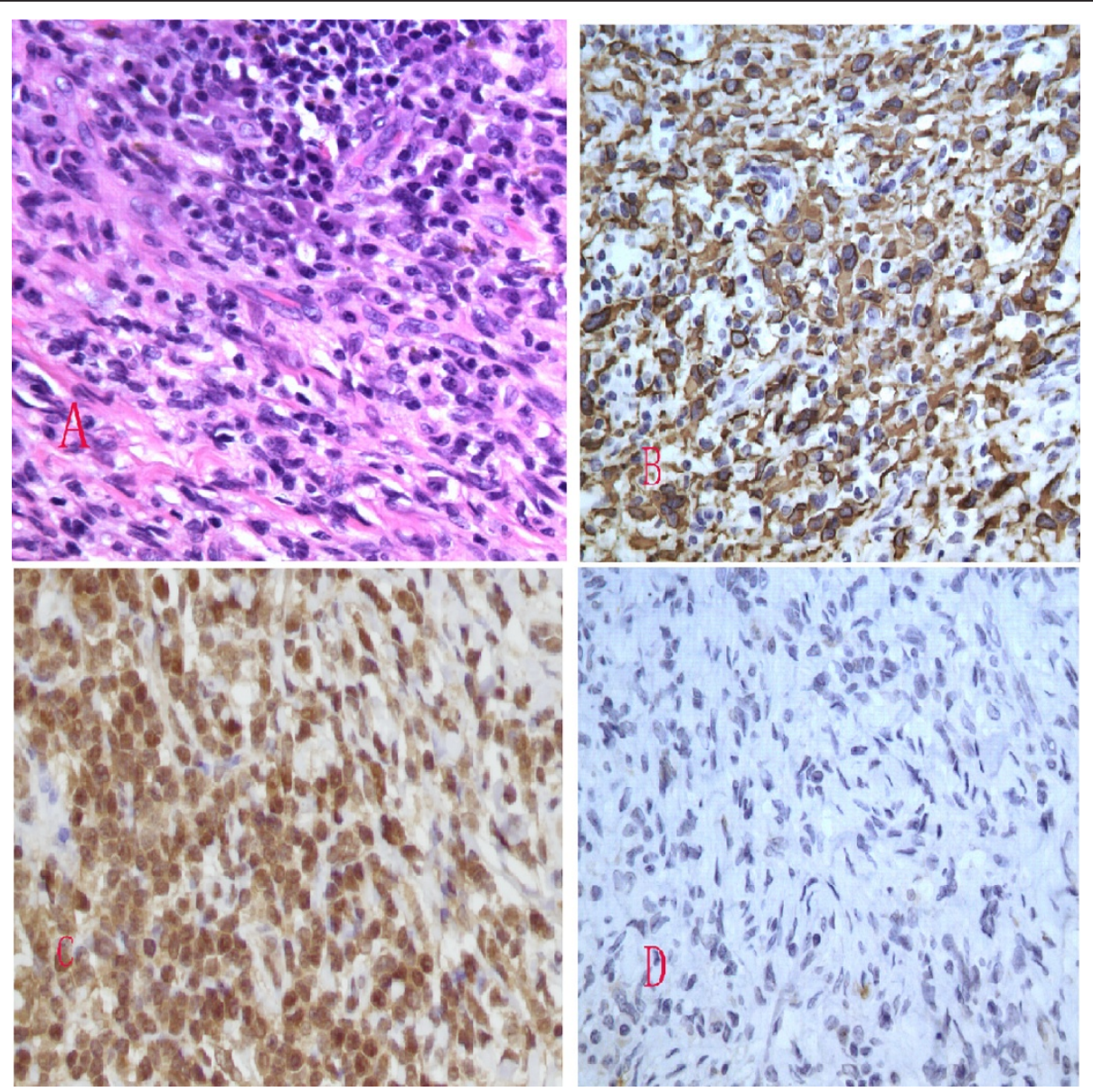

Figure 2 Routine pathological examination demonstrated that the tumour was composed of short spindle cells arranged as weaving The spindle cells in some areas were rich and some cells were atypia and mitotic, mixed with inflammatory cells such as lymphocytes and plasma cells arranged as cluster(A:HE $\times 40)$. Immunohistochemical analysis was positive for the expression of desmin $(B$ : EliVision $\times 40)$ and AKT(3 C: EliVision $\times 40$ ), focal positive for S-100 protein(D: EliVision $\times 40)$.

nervous system [5], abdomen [7], orbit [7], extremities [7], and oral cavity [8]. Tonsillar IMT is rare. In 1984, Weilbaecher et al. were the first to report IMTs of the tonsil [12]. We reviewed the English-language literature regarding IMTs of the tonsil from 1984 to 2011, and only six cases were reported (including the case described herein) (Table 1) [9-13]. The patient group consisted of two males and four females. The age of the patients ranged from 10 to 63 years at initial presentation, with a mean age of 43 years. The symptoms included sore throat, odynophagia, pain in the neck region, cough with vomiting, and dyspnea (in a young female). Two patients were asymptomatic at initial presentation, one had only an enlarged tonsil, and one had a mass in the left tonsil. There were four cases with IMT located in the left tonsil and two cases with IMT in the right tonsil.

Although debate exists as to whether IMT is a pseudotumor or a neoplasm, the concept of IMT as a neoplasm was recently solidified [7] with the discovery of cytogenetic aberrations and the subsequent recognition of ALK gene rearrangements on the short arm of the chromosome as a recurrent aberration [8]. However, the etiology, benign or malignant nature, and prognosis of IMT remain unknown and controversial. Our previous reports and other studies revealed that IMTs originating in different organs may lead to diverse etiologies and clinicopathologic features $[2,3,7,8]$. Etiologies at the other sites may be infectious [14], traumatic [15], or autoimmune syndromic [5]. Viruses that are suspected to be involved in the development of IMTs include HIV [16], HHV-8 [4], and EBV [17]. Some investigators consider it to be an immunologic response to an infectious agent $[16,17]$. For tonsillar IMT, two patients were in an immunodepressive state $[11,12]$ and one was a pregnant woman [10]. The patient with IMT of the tonsil, reported by Newman and Shinn (1995), had been on long-term prednisone for asthma and retroperitoneal fibrosis [12]. Gangopadhyay et al. reported that 
Table 1 Clinical Features of IMT Cases in the tonsil

\begin{tabular}{|c|c|c|c|c|c|c|c|}
\hline Author & $\begin{array}{l}\text { Age/ } \\
\text { sex }\end{array}$ & past history & Symptom & $\begin{array}{l}\text { Size } \\
(\mathrm{cm})\end{array}$ & Duration & Treatment & $\begin{array}{l}\text { Follow- } \\
\text { up }\end{array}$ \\
\hline Present & $51 / F$ & no past medical history of note & $\begin{array}{l}\text { A progressive enlarged } \\
\text { mass in the left tonsil }\end{array}$ & $\begin{array}{l}2.6 \times \\
1.8\end{array}$ & 3 yrs & $\begin{array}{l}\text { Tonsillectomy } \\
\text { (left) }\end{array}$ & $\begin{array}{l}3 \mathrm{~m} \\
\text { NED }\end{array}$ \\
\hline $\begin{array}{l}\text { Grube-Pagola } \\
\text { et al }(2011)^{12}\end{array}$ & $10 / F$ & no past medical history of note & $\begin{array}{l}\text { pain in the neck region, } \\
\text { cough with vomiting, } \\
\text { dyspnoea and dyslexia }\end{array}$ & $\begin{array}{l}5.2 \times \\
2.4 \times \\
1.5\end{array}$ & $11 \mathrm{~m}$ & $\begin{array}{l}\text { Bilateral } \\
\text { tonsillectomy } \\
\text { (lesion in the } \\
\text { left tosil) }\end{array}$ & NA \\
\hline $\begin{array}{l}\text { Magill } \\
\text { et al }(2010)^{13}\end{array}$ & $28 / F$ & pregnant woman & $\begin{array}{l}\text { sore throat, fever and } \\
\text { malaise }\end{array}$ & NA & 10-day & $\begin{array}{l}\mathrm{CO}_{2} \text { laser } \\
\text { (right) }\end{array}$ & $\begin{array}{l}13 \mathrm{~m}, \\
\text { NED }\end{array}$ \\
\hline $\begin{array}{l}\text { Gangopadhyay } \\
\text { et al }(1997)^{14}\end{array}$ & $\begin{array}{l}41 / \\
M\end{array}$ & $\begin{array}{l}\text { chronic renal failure received a cadaveric renal } \\
\text { transplant, } \mathrm{HCV}+\text {, prednisone, azathioprine, enalapril } \\
\text { cyclosporine since renal transplant. }\end{array}$ & $\begin{array}{l}\text { lump in the throat, } \\
\text { odynophagia }\end{array}$ & $\begin{array}{l}2 \times 2 \\
\times 2\end{array}$ & $2 \mathrm{~m}$ & $\begin{array}{l}\text { Tonsillectomy } \\
\text { (left) }\end{array}$ & $\begin{array}{l}10 \mathrm{~m} \text {, } \\
\text { NED }\end{array}$ \\
\hline $\begin{array}{l}\text { Newman et al } \\
(1995)^{15}\end{array}$ & $62 / F$ & $\begin{array}{l}\text { Asthma, retroperitoneal fibrosis, } \\
\text { Prednisone(o.d) }\end{array}$ & odynphagia & $\begin{array}{l}3.5 \times \\
2.5 \times \\
2\end{array}$ & $2 \mathrm{~m}$ & $\begin{array}{l}\text { Tonsillectomy } \\
\text { (left) }\end{array}$ & $\begin{array}{l}16 \mathrm{~m} \\
\text { NED }\end{array}$ \\
\hline $\begin{array}{l}\text { Weilbaecher } \\
\text { et al }(1984)^{16}\end{array}$ & $\begin{array}{l}63 / \\
M\end{array}$ & no past medical history of note & an enlarged right tonsil & $\begin{array}{l}2.5 \times \\
1.5 \times \\
1\end{array}$ & NA & $\begin{array}{l}\text { Tonsillectomy } \\
\text { (right) }\end{array}$ & NA \\
\hline
\end{tabular}

NA not available; NED no evidence of disease.

the patient had received long-term prednisone and other immunosuppressants following cadaveric renal transplant 9 years previously [11]. Magill et al. reported a pregnant woman with IMT in the right tonsil [10]. They suggested that pregnancy is an immunomodulated state, even during the earliest gestational period [10]. The present patient was immunocompetent.

Magill et al. mentioned that CT confirmed the presence of an enlarged right tonsil along with right-sided nodes, but did not supply any CT imaging [10]. Here, we first describe CT imaging of tonsillar IMT. CT revealed a $2.6 \times$ $1.8 \mathrm{~cm}$ irregular soft tissue mass between the left tonsil and the base of the tongue that did not invade surrounding structures and was not enhanced on contrastenhanced imaging. These findings suggested that the mass might have been a benign tumor. The results were confirmed by surgery and pathology. The surgical specimen showed a smooth surface with some small nodules, which lead to the appearance of an irregular soft tissue mass on CT imaging. Thus, preoperative recognition of this benign lesion on CT is important to avoid unnecessary radical resection. Our imaging findings were not similar to those of other IMTs in the head and neck [18]. Most IMTs on contrast-enhanced images show early enhancement, and sinonasal IMTs have a more aggressive appearance [18]. On CT, a moderately enhanced mass is usually seen in orbital IMTs, accompanied by fat infiltration or edema [18]. Our case showed no enhancement on contrastenhanced imaging and did not involve surrounding tissue.

IMTs arising in mesenteric, omental, peritoneal, pelvic, and retroperitoneal sites [19], and the maxillary sinus [20] tend to recur, with a potential for metastatic spread in rare instances $[2,3,20]$. In the six tonsillar IMTs reported, there were no recurrences or metastases.
This suggests that tonsillar IMTs may be benign and have a good outcome. However, the prognosis, recurrence, and metastatic rate have not been confirmed in a larger series, and there is a lack of long-term follow-up.

The optimal treatment for IMTs at other sites is still controversial, but excision of the tonsils with IMT, either by tonsillectomy or excision with a $\mathrm{CO}_{2}$ laser, seems to be an effective treatment based on the outcome of four tonsillar IMTs [10-12]. Treatment experience will continue to accumulate along with increases in the number of tonsillar IMTs.

\section{Consent}

Written informed consent was obtained from the patient for publication of this Case report and any accompanying images. A copy of the written consent is available for review by the Editor-in-Chief of this journal.

\section{Abbreviations}

IMT: Inflammatory myofibroblastic tumor; CT: Computed tomography; EBV: Epstein-Barr virus; HIV: Human immunodeficiency virus; USG:

Ultrasonography; IHC: Immunohistochemical; PCR: Polymerase chain reaction. The English in this document has been checked by at least two professional editors, both native speakers of English. For a certificate, please see: http:// www.textcheck.com/certificate/nSTIES

\section{Acknowledgements}

The immunohistochemical analysis for this studies was supported by Department of Science and Technology of Zhejiang Provincial (contract grant number: 2009 (33026) and Health Bureaue of Zhejiang Provincial (contract grant number:2010KYA062)

\section{Author details}

'Department of Otolaryngology, The First Affiliated Hospital, College of Medicine, Zhejiang University, Hangzhou, Zhejiang 310003, China.

${ }^{2}$ Department of Otolaryngology, The Second Hospital of Jiaxing City, Jiaxing, Zhejiang Province 314000, China. ${ }^{3}$ Key Laboratory of National Infectious Diseases, Institute of Infectious Diseases, First Affiliated Hospital, School of 
Medicine, Zhejiang University, Hangzhou, 310003, China. ${ }^{4}$ Department of Radiology, The First Affiliated Hospital, College of Medicine, Zhejiang University, Hangzhou, Zhejiang 310003, China.

\section{Authors' contributions}

Yun-Zhen Luo designed the manuscript. Li-Bo Dai and Xing-Mei Luo aided in the surgery and collected the materials. Shui-Hong Zhou performed the surgery and wrote the manuscript. J un Fan did the laboratory examination. Ling-Xiang Ruan analysed the imaging of $\mathrm{CT}$. All authors read and approved the final manuscript

\section{Competing interests}

The authors declare that they have no competing interests.

Received: 4 February 2012 Accepted: 9 March 2012

Published: 9 March 2012

\section{References}

1. Saab ST, Hornick JL, Fletcher CD, Olson SJ, Coffin CM: IgG4 plasma cells in inflammatory myofibroblastic tumor: inflammatory marker or pathogenic link. Mod Pathol 2011, 24:606-612.

2. Lu CH, Huang HY, Chen HK, Chuang JH, Ng SH, Ko SF: Huge pelviabdominal malignant inflammatory myofibroblastic tumor with rapid recurrence in a 14-year-old boy. World I Gastroenterol 2010, 16:2698-2701.

3. Song Z, Zhang Y, Xu X, Li F, Shi T, Li Z, Zhou Q: Inflammatory myofibroblastic tumor invading pulmonary trunk with multiple mediastinal lymph node metastasis. Ann Thorac Surg 2011, 92:e15.

4. Graefe H, Stellmacher F, Sotlar K, Wollenberg B, Gehrking E: Inflammatory pseudotumor of the hypopharynx: clinical diagnosis, immunohistochemical findings and treatment of this rare disease. In Vivo 2008, 22:817-820.

5. Sanahuja J, Ordoñez-Palau S, Begué R, Brieva L, Boquet D: Primary Sjögren Syndrome with tumefactive central nervous system involvement. AJNR Am I Neuroradiol 2008, 29:1878-1879.

6. Zheng Z, Pan Y, Pan T, Li J: Coexistent pulmonary inflammatory pseudotumor and carcinoma in one patient: does positron emission tomography/computed tomography help. Ann Thorac Surg 2011, 91:e43.

7. Coffin $C M$, Hornick JL, Fletcher CD: Inflammatory myofibroblastic tumor comparison of clinicopathologic, hstologic, and immunohistochemical features including ALK expression in atypical and aggressive cases. Am J Surg Pathol 2007, 31:509-520.

8. Binmadi NO, Packman H, Papadimitriou JC, Scheper M: Oral inflammatory myofibroblastic tumor: case report and review of literature. Open Dent $J$ 2011, 5:66-70.

9. Grube-Pagola P, Carrasco-Daza D, Alderete-Vázquez G, Gutiérrez-Butanda J: Inflammatory myofibroblastic tumour of the tonsil: case report and literature review. Acta Otorrinolaringol Esp 2011, [Epub ahead of print] in press.

10. Magill JC, Ferguson MS, Butler CR, Sandison A, Grant WE: Inflammatory myofibroblastic tumour of the tonsil: case report and literature review. J Laryngol Otol 2010, 124:1123-1125.

11. Gangopadhyay K, Mahasin ZZ, Kfoury H, Ali MA: Inflammatory myofibroblastic tumour of the tonsil. J Laryngol Otol 1997, 111:880-882.

12. Newman JP, Shinn JB: Inflammatory pseudotumour of the tonsil. Otolaryngol Head Neck Surg 1995, 113:798-801.

13. Weilbaecher TG, Sharma DP: Plasma cell granuloma of the tonsil. $J$ Surg Oncol 1984, 27:228-231.

14. Androulaki A, Papathomas TG, Liapis G, Papaconstantinou I, Gazouli M, Goutas N, Bramis K, Papalambros A, Lazaris AC, Papalambros E: Inflammatory pseudotumor associated with Mycobacterium tuberculosis infection. Int J Infect Dis 2008, 12:607-610.

15. Perera MT, Wijesuriya SR, Kumarage SK, Ariyaratne MH, Deen Kl: Inflammatory pseudotumour of the liver caused by a migrated fish bone. Ceylon Med J 2007, 52:141-142.

16. Gonzalez-Duarte A, Sullivan S, Sips GJ, Naidich T, Kleinman G, Murray J, Morgello S, Germano I, Mullen M, Simpson D: Inflammatory pseudotumor associated with HIV, JCV, and immune reconstitution syndrome. Neurology 2009, 72:289-290.

17. Kiryu S, Takeuchi K, Shibahara J, Uozaki H, Fukayama M, Tanaka H, Maeda E, Akahane M, Ohtomo K: Epstein-Barrvirus-positive inflammatory pseudotumour and inflammatory pseudotumour-like follicular dendritic cell tumour. Br J Radiol 2009, 82:e67-e71.

18. Yamrubboon W, Phongkitkarun S, Jaovisidha S, Sirikulchayanonta V, Tapaneeyakorn J, Siripornpitak S: Inflammatory myofibroblastic tumor ofabdomen: computerized tomographic (CT) and pathological findings. J Med Assoc Thai 2008, 91:1487-1493.

19. Gleason BC, Hornick JL: Inflammatory myofibroblastic tumours: where are we now? J Clin Pathol 2008, 61:428-437.

20. Zhou SH, Ruan LX, Xu YY, Wang SQ, Ren GP, Ling L: Inflammatory myofibroblastic tumour in the left maxillary sinus: a case report. Chin Med J 2004, 117:1597-1599, (Engl).

doi:10.1186/1758-3284-4-4

Cite this article as: Luo et al:: Etiology analysis and computed tomography imaging of a tonsillar inflammatory myofibroblastic tumor: report of an immunocompetent patient and brief review. Head \& Neck Oncology 2012 4:4.

\section{Submit your next manuscript to BioMed Central and take full advantage of:}

- Convenient online submission

- Thorough peer review

- No space constraints or color figure charges

- Immediate publication on acceptance

- Inclusion in PubMed, CAS, Scopus and Google Scholar

- Research which is freely available for redistribution

Submit your manuscript at www.biomedcentral.com/submit

Ciomed Central 